Archived version from NCDOCKS Institutional Repository http://libres.uncg.edu/ir/asu/

\title{
Appalachỉan
}

B O O N E, N O R T H C A R O L I N A

\section{The Role Of Pre-IPO Financial Indicators And Intermediaries In Aftermarket Performance And Survival In The US Biopharmaceutical Market}

\author{
By: David R. Williams and Carlton C. Young
}

\begin{abstract}
This paper examines factors affecting the stock price, net proceeds, and subsequent survival of biopharmaceutical firms that have gone public between 1996 and 2007 in the USA. We find that the financial condition of biopharmaceutical firms going public has deteriorated. The results also indicate that the financial condition of the firm prior to its going public and the intermediaries associated with the firm and initial public offering have little effect on first-day price increases. The findings, however, indicate that several of these financial indicators, and having prestigious underwriters, do have a significant effect on the amount of net proceeds received by the firm.
\end{abstract}

Williams, D.R., Young, C.C. The Role of Pre-IPO Financial Indicators and Intermediaries in Aftermarket Performance and Survival in the US Biopharmaceutical Market. J Pharm Innov 7, 127-139 (2012). https:// doi.org/10.1007/s1 2247-012-9131-0. Publisher version of record available at: https://link.springer.com/ article/10.1007/s1 2247-012-9131-0 


\title{
The Role of Pre-IPO Financial Indicators and Intermediaries in Aftermarket Performance and Survival in the US Biopharmaceutical Market
}

\author{
David R. Williams • Carlton C. Young \\ Published online: 3 August 2012 \\ (C) Springer Science+Business Media, LLC 2012
}

\begin{abstract}
This paper examines factors affecting the stock price, net proceeds, and subsequent survival of biopharmaceutical firms that have gone public between 1996 and 2007 in the USA. We find that the financial condition of biopharmaceutical firms going public has deteriorated. The results also indicate that the financial condition of the firm prior to its going public and the intermediaries associated with the firm and initial public offering have little effect on first-day price increases. The findings, however, indicate that several of these financial indicators, and having prestigious underwriters, do have a significant effect on the amount of net proceeds received by the firm.
\end{abstract}

Keywords Initial public offering $\cdot$ Net proceeds $\cdot$ Survival

\section{Introduction}

Expenditures on new drugs and therapeutics created by biotechnology and pharmaceutical firms (collectively termed here as "biopharmaceuticals") represent an increasing portion of US citizens' healthcare dollar [1,2]. The costs associated with bringing a new pharmaceutical product to market has been studied extensively, with recent estimates of costs related to new pharmaceutical and biotechnology products in the USA now exceeding one billion dollars each [3]. In addition to these costs, the time from product

D. R. Williams $(\bowtie)$

Department of Nutrition and Health Care Management, College of Health Sciences, Appalachian State University, Boone, NC 28608, USA

e-mail: willimsdr@appstate.edu

C. C. Young

Division of Business, Mississippi State University,

2212 5th St. \#309,

Meridian, MS 39301, USA

e-mail: CYoung@meridian.msstate.edu conception to market can be 12 to 15 years or more with high failure rates common among these products and firms $[4,5]$. The reward for firms succeeding in this market sector can be significant [6], however, with many US pharmaceutical firms experiencing double-digit annual growth rates over the past decade or more [7].

Because of these factors, firms seeking entry into this market typically receive funding from multiple sources $[8$, 9]. Historically, established pharmaceutical firms have been the single largest provider of these funds $[10,11]$. Another source of funding for many new biopharmaceutical firms is from the public markets by way of an initial public offering (IPO). Within the IPO literature, previous empirical work has primarily focused on the general population of US IPOs [12], with post-IPO stock price performance being studied at length over the past few decades [13].

We know far less about biopharmaceutical firms' IPO performance as this has received little attention in the literature [14]. To address this deficiency, this paper examines pre-IPO financial indicators and their relationship to aftermarket (e.g., NASDAQ) performance and survival of US biopharmaceutical firms that went public in the 12-year period from 1996 through 2007. Our purpose is to explore changes in financial condition of these biopharmaceutical IPOs over time and to investigate whether these pre-IPO financial indicators correlate with short- and long-term changes in this market. Among others, Ritter and Welch [15] have encouraged further work in subsamples of the general IPO market to help clarify our understanding of these issues. This should be of interest to scholars and biopharmaceutical firms as these issues relate to efficiencies in these markets $[15$, 16], with inefficient markets potentially reducing the funds available to finance new drugs and therapies. Commentators $[8,17,18]$ have noted that recent events in the capital markets indeed may have lessened access to resources for new firms and technologies. 
In the general IPO literature, the performance issue of increases in first-day returns, known as underpricing, has received significant attention [19]. Ritter and Welch [15] noted that between 1980 and 2001, US IPOs' first-day stock prices increased on an average of $18.8 \%$. Loughran and Ritter [20] observed that between 1990 and 1998, IPO issuers would have gained an extra \$27 billion in net proceeds had their initial stock price (known as the offer price) reflected the price the stock sold at the end of its first day of trading. Loughran and Ritter ([20], p. 414), however, found that most of this money "left on the table" comes from "a minority of IPOs." In a different study, Loughran and Ritter [21] found great variation of underpricing within this period. For instance, they find that first-day average stock prices increased $7 \%$ during the 1980 s, $15 \%$ from 1990 through 1998, and $65 \%$ during the internet bubble of 1999 and 2000. Despite this increase in first-day stock price, Peristiani and Hong [16] studying all US IPOs between 1980 and 2000 , found that the quality of pre-IPO financial indicators had gradually deteriorated over this time period.

Most of the published research on biopharmaceutical IPOs has been specific to biotechnology firms. The majority of this IPO research has examined biotechnology firms that went public in the 1990s prior to the migration of venture capital into this market sector following the internet bubble. Beginning around the year 2000, the biotechnology and medical device industries became the largest areas for venture capital investment. These two industries received $31 \%$ of all venture capital investment or $\$ 9.1$ billion in 2007 [22]. By the end of 2007, there were 386 publicly traded biotechnology firms in the USA [23]. About a third of these biotechnology firms went public after the internet bubble. Publicly traded biotechnology firms have a total market capitalization of about $\$ 300$ billion [24]. We study both biotechnology and pharmaceutical firms as these industries are merging. Studies close to our own remain sparse, however, with extant research differing in terms of setting, time period, and variables.

Our sample includes biopharmaceutical firms that have gone public since the time of much of the extant literature on the general IPO market and biotechnology firms was written and since the increased migration of funds by venture capital investors. We look at the biopharmaceutical's financial and intermediaries' variables relationship to (1) changes in stock prices at multiple time periods and by different types (e.g., drug development firms and complements), (2) the net proceeds raised by the initial offer, and (3) IPO survivability.

\section{Theoretical Framework and Research Hypotheses}

The valuation of IPOs is one of the most intriguing phenomena undertaken by academicians and investors alike.
There are two broad valuation approaches in the general IPO literature. The first approach is one in which firm value is determined based on its own fundamentals without considering other firms, and the second is one in which firm value is estimated indirectly by prices of comparable firms [25]. Our study has elements of both approaches.

Frequently mentioned in these valuation approaches are the two interrelated issues of timing and costs. The issue of "timing" is concerned with the relationship of new stock issuance relative to the performance of the average existing publicly traded firm [26]. Practitioners and researchers both are interested in whether or not there is a better time to issue stock. IPO markets typically are considered either "hot" or "cold," with much of the extant research focusing on "hot markets" [27]. Hot markets occur when the stock price of new issues rapidly increases above their offering prices and last for an extended period. The findings of the hot market literature related to performance are inconclusive, however. For example, early work by Ibbotson and Jaffe [28] suggests that IPOs might be better off going public in a cold market. Ritter [27], however, noted that the IPO market was segmented with various segments of the market performing differently. Williams and Young [29] noted that the biopharmaceutical IPO market between 1996 and 2003 was "hotter" than the general US IPO market in only 1 year. Our paper is only secondarily concerned with the timing or hot markets issue.

Issues surrounding IPO costs include direct cash expenses such as legal and accounting [30], investment bank's commission [31], and mispricing [32, 33]. Research on the costs surrounding the mispricing of new issues has received a great deal of attention. This research is concerned with establishing a price at which to sell the shares on the common market and involves an iterative set of negotiations among the firm going public, the underwriters, and aftermarket investors [33]. In its most basic form, pre-IPO investors typically sell their stock to investment banks (e.g., underwriters) just prior to the IPO at a specified price (called the offer price). The investment banks then sell this stock in the aftermarket to the general public (e.g., institutional investors and individuals). The difference between the offer price and the price that the general public pays in the aftermarket creates the mispricing issue. When the general public persistently pays above or below the offer price then this creates a hot or cold market.

Mispricing can take the form of "underpricing" which is when the stock price at the close of the first day of trading is higher than the offer price, or "overpricing" which is when the stock price at the close of the first day of trading is lower than the offer price. Most studies have found underpricing to be the predominate form of mispricing [34]. As stated earlier, Loughran and Ritter [20] noted that between 1990 and 1998, pre-IPO investors relinquished \$27 billion due to 
the underpricing of their stock. Subsequently, Nimalendran, Ritter, and Zhang [35] found that during the internet bubble years of 1999 and 2000, pre-IPO investors would have gained an additional $\$ 63.5$ billion had it not been for underpricing.

Several explanations have been put forward to explain the underpricing issue. We touch on only a few of these here, and note that Ritter and Welch [15] provide a review of the theories associated with underpricing. Rock's [36] "winners curse" is one of the early explanations and states that informed investors have access to the true value of new issues while uninformed investors initially subscribe indiscriminately to all new issues. However, realizing that they will be paying a premium for the stock, the uninformed investor subsequently chooses to stay out of the market. In order to ensure that all the IPO shares sell at the IPO, the new issuing firm has to underprice its shares to entice the uninformed investors. A second explanation is put forward by Tinic [37] who hypothesizes that new issuers underprice shares to act as insurance against legal liability. Shiller [38] proposes that the IPO market is subject to "fads" that affect market prices, with underwriters and other investors moving from one area of investment to the next. Baron [39] notes that underpricing lowers the underwriter's marketing costs.

Signaling theory [40] also has been used in numerous studies $[9,41]$ to describe IPO activity, with it being suggested that the endorsement of prestigious underwriters influence the investor's view of a high-quality new issue and thus encourages underpricing. Loughran and Ritter [20] use prospect theory [42] to suggest that pre-IPO investors are more tolerant of excessive underpricing if they simultaneously learn about aftermarket valuation that is higher than what they expected. This is to say that the greater the recent increase in their wealth, the less is the bargaining effort of pre-IPO investors in their negotiations over the offer price with the underwriters. Our purpose here is to note that (1) underpricing is recognized as a common phenomenon within the general population of IPOs, (2) underwriters tend to suppress offer prices, and (3) there is little consensus in the literature as to "whether underpricing is a preferred or unwelcome outcome of the IPO process" ([19], p. 274).

Figure 1 illustrates the mispricing issue for biopharmaceutical firms. In the first half of Fig. 1, we have separated firms that are primarily engaged in drug/therapy development from firms that are complements (see explanation in "Sources and Construction of the Dataset"). From Fig. 1, we can see that both drug development and complement IPOs experienced wide swings in mispricing of their stock but less so more recently. The typical firm during this 12 -year period $(N=215)$ experienced $16.2 \%$ underpricing. The second half of Fig. 1 shows the changes in stock price on certain anniversary dates (e.g., 1 year after IPO) relative to its initial offer price. Here, too, we see wide swings in

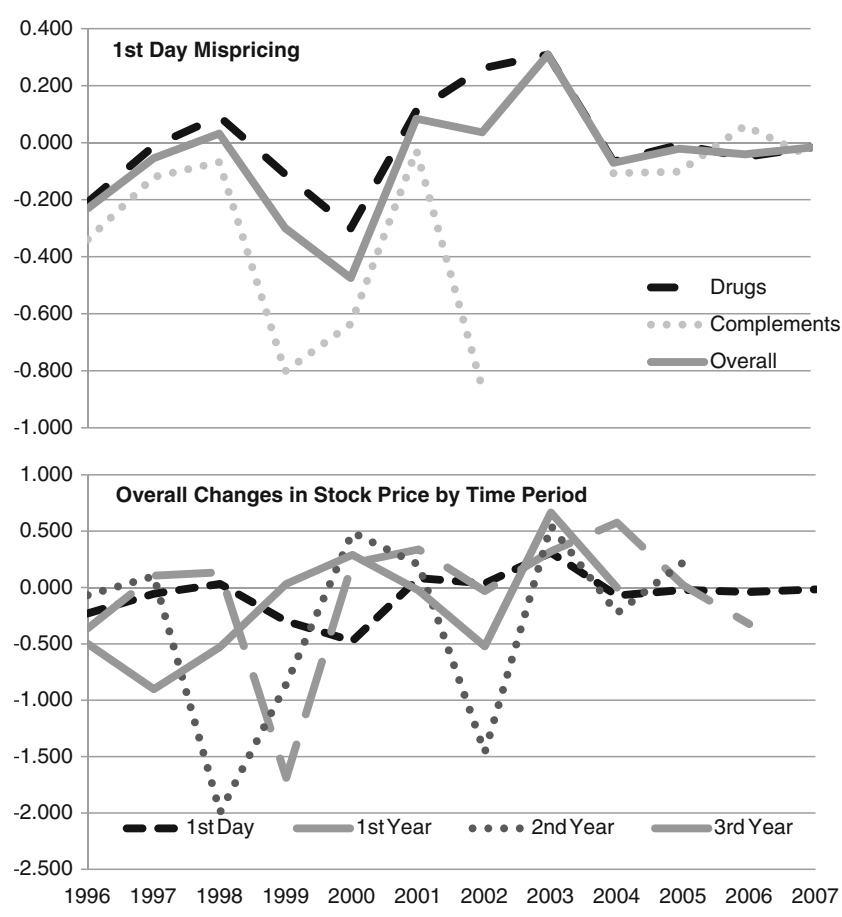

Fig. 1 Changes in stock prices. Negative numbers represent percent increase of stock price at the end of period above offer price

changes in stock price. The typical firm whose stock traded 1 year or more $(N=189)$ experienced a $1.6 \%$ increase in stock price on its first-year IPO anniversary date relative to its initial offer price. This compares to the typical firm whose stock traded 3 years or more $(N=133)$ experiencing a $14.1 \%$ stock price increase from its initial offer price on its third-year IPO anniversary.

There are only a handful of studies in this setting that are close in nature to the current study. For example, Guo, Lev, and Zhou [25] examine financial and nonfinancial information to explain the initial offer value (i.e., product of initial offer price and expected number of shares outstanding), end offer value (i.e., product of actual offer price and expected number of shares outstanding), and aftermarket value (i.e., product of closing price and total amount raised on the first day of trading) of 122 biotechnology IPOs from the 1990s. They find that nonfinancial measures play an important role in explaining offer values and aftermarket value. Williams et al. [14] study governance and agency issues related to wealth creation (e.g., 3-year average returns on assets and equity) in 182 biotechnology and healthcare IPOs between 1996 and 1999. They find little relationship between these variables.

Tan and Lim [43] study 486 biotechnology firms (not IPOs) from 1990 to 2001 to determine if accounting variables reflect information used by investors in valuing a firms' equity over numerous time periods. They find the accounting variables to be value relevant but with little explanatory power. Williams, Duncan, and Ginter [9] explore the relationships 
among board characteristics, previous IPO underpricing, offer price, and expected offer amount raised on 182 healthcare and biotechnology IPOs that went public from 1996 through 1999. They find significant relationships between certain board characteristics and offer price. Xu [44] examines 194 biotechnology firms (not IPOs) to see if research and development (R\&D) strategy (i.e., pursuing a diversified or concentrated portfolio of drugs or therapies) affects daily stock price volatility. Xu [44] finds that R\&D strategy does have an effect on stock price volatility. Thus, there exists the beginnings of research around this topic in this setting; however, there is no direct research on mispricing, amount actually raised during the entire IPO process, or long-term performance and survival.

Ultimately, underpricing is the result of aftermarket investors valuing the stock at a higher price than the underwriters do. Some researchers [20,45] argue that underwriters not only have a propensity to keep the initial offer prices low but are also incentivized to underprice IPOs. Furthermore, Tan and Lim ([43], p. 233) note that many view a biotechnology firm's stock as "speculative in nature and resembl[ing] a gamble." This is because the technology within much of this industry is still developing [46], with little knowledge of the true product development costs [47], or as Robbins-Roth [48] observes the discovery process for many of these products remains serendipitous.

Given that mispricing does occur in this market sector, the great uncertainty of technological development in these industries and for each firm, and the paucity of information about the firm available to the investor, we believe that it is reasonable to expect to see aftermarket investors relying heavily on financial information to value the stock-specifically that information found in the firm's audited financial statements. Leone, Rock, and Willenborg [49] note that investors do use data in the firm's prospectus, especially how they tend to use the funds of the IPO. Thus, we agree with Loughran and Ritter [20] and others that underwriters for various reasons tend to keep the offer price low, and we propose that aftermarket investors with little information (or ability to interpret information in this field [50]) other than financial data tend to bid up firms in relatively better financial condition compared with other firms in this industry. Hence, we expect to see value-relevant results related to mispricing and financial indicators similar to Tan and Lim's [43] results related to the non-IPO biotechnology firms' stock prices. Thus, we hypothesize:

$\mathrm{H}_{1}$. All else equal, firms in a better financial condition will experience greater underpricing than firms in a lesser financial condition.

Also implicit in this literature is the belief that the measure of a successful IPO is not necessarily limited to the offer or stock price but includes the amount raised by the
IPO $[9,20]$. At this stage, it is primarily the funds from the IPO that allow the firm to survive and pursue its purpose. Regardless of the pre-IPO investors' ability to limit the amount of funds left on the table in terms of the difference in offer and aftermarket price, we would expect to see biopharmaceutical firms seeking to maximize the amount raised during the IPO, with firms in better financial condition in a more able position to do this. Loughran and Ritter [20] suggest that pre-IPO investors do not get upset about underpricing as long as their overall wealth increases, with underwriters determining not just the offer price but the volume sold as well [15]. The total amount raised in an IPO can be considered one factor in this wealth creation process. Thus, we hypothesize:

$\mathrm{H}_{2}$. All else equal, firms in a better financial condition will receive a greater amount of net proceeds from the initial public offering than firms in a lesser financial condition.

Notwithstanding the above, not all financial indicators may be of the same value for all firms, industries, and investors. For biopharmaceutical companies, expenditures on research and development may be viewed as exemplifying the pre-IPO owner's commitment to the firm. Additionally, several studies on technology firms [51, 52] have shown that the market is favorable to expenditures on research and development. This especially may be true for IPOs that are engaged in drug/therapy development more so than for other firms in this industry. Thus, we hypothesize:

$\mathrm{H}_{3 \mathrm{a}}$. All else equal, firms that invest a greater amount in $\mathrm{R} \& \mathrm{D}$ in the year prior to the IPO will experience a greater amount of underpricing than firms that invest a lesser amount on R\&D.

$\mathrm{H}_{3 \mathrm{~b}}$. All else equal, drug development firms that invest a greater amount in R\&D in the year prior to the IPO will experience a greater amount of underpricing than drug development firms that invest a lesser amount on $R \& D$

$\mathrm{H}_{4 \mathrm{a}}$. All else equal, firms that invest a greater amount in $R \& D$ in the year prior to the IPO will receive a greater amount of net proceeds from the initial public offering than firms that invest a lesser amount on R\&D.

$\mathrm{H}_{4 b}$. All else equal, drug development firms that invest a greater amount in R\&D in the year prior to the IPO will receive a greater amount of net proceeds from the initial public offering than drug development firms that invest a lesser amount on R\&D.

The general IPO literature has also found intermediaries to play a significant role in IPO development and pricing. This literature relates to the involvement of venture capitalists and underwriters. Within the literature, both parties have 
been purported to send signals of high-quality investment opportunities [9, 19]. In particular, underwriter reputation has been found to be correlated with favorable offerings [25]. Fernando, Krishnamurthy, and Spindt [53] found IPOs between 1980 and 1998 with underwriters with higher reputations being associated with firms having higher offering prices and also greater survival rates. They do not include financial indicators in their study. Venture capitalists also have been seen as having a significant positive impact on technological innovation [54] that act as an active bridge or intermediary between optimistic entrepreneurs and conservative institutional investors [55]. Thus, we hypothesize:

$\mathrm{H}_{5 \mathrm{a}}$. All else equal, firms with venture capital involvement will experience greater underpricing than firms without venture capital involvement.

$\mathrm{H}_{5 \mathrm{~b}}$. All else equal, firms with venture capital involvement will receive a greater amount of net proceeds from the initial public offering than firms without venture capital involvement.

$\mathrm{H}_{6 \mathrm{a}}$. All else equal, firms with underwriters with greater reputations will experience more underpricing than firms with underwriters with lesser reputations.

$\mathrm{H}_{6 \mathrm{~b}}$. All else equal, firms with underwriters with greater reputations will receive a greater amount of net proceeds from the initial public offering than firms with lesser underwriter reputations.

Recently, the long-run performance of IPOs has also gained attention in the literature, as this issue relates to the question of efficiency in public markets [15]. Efficient market proponents argue that once an IPO is publicly traded, it is similar to any other stock and thus the aftermarket stock price should reflect the stock's intrinsic value $[51,56]$. Overall, IPOs have underperformed compared with other publicly traded firms [57]. According to Ritter and Welch [15], there is a conventional wisdom that the quality of firms deteriorates as more firms issue stock. We believe that this might also be true with biopharmaceutical firms in that the venture capital and IPO markets gained interest in this area after the internet bubble. In addition, as this is a research and capital-intense market sector [1], we believe that firms with greater resources may be able to survive longer. Thus, we hypothesize:

$\mathrm{H}_{7 \mathrm{a}}$. All else equal, firms with better pre-IPO financial indicators will perform better in terms of changes in stock price in the long run than firms with lesser preIPO financial indicators.

$\mathrm{H}_{7 \mathrm{~b}}$. All else equal, the quality of biopharmaceutical firms as measured by pre-IPO financial indicators will have deteriorated over time.

$\mathrm{H}_{8 \mathrm{a}}$. All else equal, firms with better pre-IPO financial indicators will be more likely to survive than firms with lesser pre-IPO financial indicators.
$\mathrm{H}_{8 \mathrm{~b}}$. All else equal, firms that raise a greater amount of net proceeds at the time of the IPO will be more likely to survive than firms that raise a lesser amount of net proceeds at the time of the IPO.

\section{Sources and Construction of the Dataset}

We collected names of biopharmaceutical IPOs from the Security and Exchange Commission's (SEC) internet site and several other internet sources (e.g., Bio.org, Biospace, BioWorld, Edgar-Online, Ernst \& Young, Hoover's, and IPO resources). We also read all news articles from the late $1990 \mathrm{~s}$ through 31 January 2008 related to public offerings from www.biospace.com to ensure that all biopharmaceutical IPOs were captured. Our sample represents biopharmaceutical firms that went public for the first time between 1 January 1996 and 31 December 2007. We end our sample in 2007 due to the financial crisis and the small number of IPOs thereafter. We exclude foreign firms filing an F-1 foreign firm's registration statement and firms that are primarily "plant and animal" firms. A small number of firms in our sample appear to be foreign firms. However, if they incorporate in the USA (usually Delaware) and file an S-1 general registration statement for US firms, we include them in the sample. We also exclude firms that went public but did not receive any direct proceeds from the sale of their stock (i.e., certain investors were cashing out all or part of their investment).

The firms in our sample represent firms directly researching and developing drugs and therapeutics for humans and complements within this market sector (i.e., contract research organizations and firms making computer software specifically for these industries). We include firms from the following standard industrial classification (SIC) codes: 2833 (medicinal chemicals and botanical products), 2834 (pharmaceutical preparations), 2835 (in vitro and in vivo diagnostic substances), 2836 (biological products), 3826 (laboratory analytical instruments), 3829 (measuring and controlling devices), 3841 (surgical and medical instruments and apparatus), 5122 (wholesale drugs), 7371 (services - computer programming services), 7372 (services - prepackaged software), 7389 (servicesbusiness services), 8071 (services-medical laboratories), and 8731 (services-commercial physical and biological research). We review their prospectuses and later filings to determine if their primary products or services are in biopharmaceuticals. Other SIC codes are also evaluated. We separate these firms into two groups. Similar to Golec and Vernon [58], we label firms with SIC codes 2834 and 2836 as "drugs" and firms with all other SIC codes as "complements." 


\section{Variables}

Mispricing is the percentage difference in the offer price and the end of the first day of trading stock price, with a negative number representing underpricing. We use the terms underpricing and mispricing interchangeably below. The offer price derives from the firm's prospectus. Historical stock price information for firms currently listed with the major US stock exchanges (e.g., New York Stock Exchange, NASDAQ, and the American Stock Exchange) is from www.biospace.com, www.finance.yahoo. com, or www.hotstocked.com. Stock price data for the firms that had terminated their listings with the SEC (and are no longer publicly traded) were collected from back issues of the Wall Street Journal. We use the percentage stock price change of the firm's stock 3 years after its IPO (i.e., (offer price - 3rdyear anniversary stock price)/offer price) as a long-term performance indicator.

Data related to an IPO's net proceeds from the initial public offering are found in the firm's first quarterly or annual report after the IPO as filed with the SEC. The net proceeds data are net of transaction costs, which typically include attorney's fees and fees and discounts to underwriters. As length of time varies per IPO, we rely upon the firm to tell us how much capital they raised. For example, Targanta's quarterly report states: "The net offering proceeds to the Company were approximately $\$ 51.4$ million after deducting underwriting discounts and commissions and offering expenses of approximately $\$ 2.1$ million.” Thus, we use $\$ 51.4$ million for the net proceeds variable for this firm.

We use four variables as proxies for financial condition: revenue generation, research and development expenditures, return on assets (ROA), and stockholder's equity. These variables are used often as proxies for financial condition in both financial and technology research (e.g., [14, 25, 43, 59]). Revenue generation is a binary term that signifies that the firm has produced revenue. ROA is derived by dividing net income by total assets. Net income and total assets are not used as proxies for financial condition in our analyses, but rather we use ROA which is a common variable found in this type of analysis. In addition to our other proxies for financial condition, we would have liked to have examined return on equity, however, for too many firms this indicator would have been undefined due to their negative worth prior to going public.

We control for the firm's age and retained equity. Retained equity signifies the percentage amount of common stock the pre-IPO owners will continue to own. We use retained equity as a control variable because this can act as a signal to potential investors regarding pre-IPO owners' commitment to the firm. Data for each firm's offer price, SIC code, age, retained equity, revenue generation, net income, total assets, stockholder's equity, research and development expense, and IPO date were collected from the IPO's prospectus as filed with the SEC and found on its website (www.sec.gov). Data related to revenue generation, net income, total assets, and research and development expense are from the audited financial statements within the prospectus and represent data for the most recent year prior to the IPO. The "age" variable is an approximation based on the year. We added 1 year to each IPO as we found one or more firms that were forming at the time of the IPO (i.e., they had only incorporated a few months before). For the firms that delisted, we include their information up until the time of their delisting. A small number of firms that delisted resumed trading over the counter as "penny stocks." We do not include over-the-counter information in this study.

There are two variables related to intermediaries: venture capital involvement and underwriter reputation. These are dichotomous variables. Firms and individuals that invested in biopharmaceutical firms prior to the IPO were crossmatched with Pratt's Guide to Venture Capital Sources [60] to determine venture capital involvement. For underwriters, we rank the lead underwriter using the "tombstone" underwriter reputation ranks provided by Carter, Dark, and Singh [61]. For the few underwriters within our study not ranked by Carter, Dark, and Singh [61], we use the Carter and Manaster [62] tombstone method to determine the underwriter's ranking.

We use delisting of the firm's stock with a major exchange as a proxy for firm survival. Delisted firms file with the SEC a termination of securities statement. We use this statement to determine delistings (along with noting the missing 31 December 2007 stock price variable) and then review other SEC filings to calculate years from IPO to termination of securities or delisting (survival).

\section{Results}

Table 1 presents summary statistics describing the data by year. There are 215 biopharmaceutical firms in our sample, and they received over $\$ 12.5$ billion in net proceeds from the sale of their stock during their initial public offering. Of note, in the first 3 years (1996-1998) of our 12-year study, the collective percentage of firms equals $25.6 \%$ of the total number of firms in our study, whereas the collective percentage of the net proceeds for these firms equals $11.8 \%$ of the total. In 6 years (e.g., 1999, 2001, 2003, 2004, 2005, and 2007), the collective percentage of firms $(38.1 \%$ of the total) corresponds roughly to the collective percentage of net proceeds (35.1\% of the total). In 3 years $(2000,2002$, and 2006), the collective percentage of firms equals $36.3 \%$ of the total, whereas the collective percentage of the net 
Table 1 IPO issuance, 1996-2007

\begin{tabular}{|c|c|c|c|c|c|c|}
\hline Year & $\begin{array}{l}\text { Number } \\
\text { of firms }\end{array}$ & $\begin{array}{l}\text { Percentage } \\
\text { of firms }\end{array}$ & $\begin{array}{l}\text { Net proceeds } \\
\text { (thousands) }\end{array}$ & $\begin{array}{l}\text { Percentage of } \\
\text { net proceeds }\end{array}$ & $\begin{array}{l}\text { Mean net proceeds } \\
\text { (thousands) }\end{array}$ & $\begin{array}{l}\text { Age } \\
\text { (years) }\end{array}$ \\
\hline 1996 & 24 & 0.112 & 717,404 & 0.057 & 29,891 & 5.8 \\
\hline 1997 & 23 & 0.107 & 567,563 & 0.045 & 24,676 & 8.6 \\
\hline 1998 & 8 & 0.037 & 200,498 & 0.016 & 25,062 & 7.6 \\
\hline 1999 & 11 & 0.051 & 590,975 & 0.047 & 53,725 & 8.4 \\
\hline 2000 & 50 & 0.233 & $3,994,735$ & 0.318 & 79,894 & 7.0 \\
\hline 2001 & 5 & 0.023 & 320,700 & 0.025 & 64,140 & 6.0 \\
\hline 2002 & 5 & 0.023 & 736,251 & 0.059 & 147,250 & 8.8 \\
\hline 2003 & 5 & 0.023 & 303,400 & 0.024 & 60,680 & 7.8 \\
\hline 2004 & 27 & 0.126 & $1,465,073$ & 0.116 & 54,261 & 8.3 \\
\hline 2005 & 14 & 0.065 & 733,517 & 0.058 & 52,394 & 7.1 \\
\hline 2006 & 23 & 0.107 & $1,934,978$ & 0.154 & 84,129 & 9.7 \\
\hline 2007 & 20 & 0.093 & $1,015,800$ & 0.081 & 50,790 & 8.2 \\
\hline Total & 215 & 100 & $12,580,895$ & 100 & 58,516 & 7.7 \\
\hline
\end{tabular}

proceeds for these firms equals $53.1 \%$ of the total. Hence, there is variance in biopharmaceutical IPO activity.

Table 2 presents mean financial data by year of IPO. These data come from the audited financial statements found in the prospectuses. In 2002, two large profitable firms went public which given the small number of IPOs for this year $(N=5)$ skewed the data for this year. The effect of these two firms is also depicted in our charts. When we exclude these two firms, the remaining three firms in 2002 have net income of -14.6 million, total revenue of 64.8 million, total assets of 182.8 million, research and development of 18.3 million, and a ROA of -15.6 . Figure 2 illustrates the ROA and stockholder's equity for these firms in the year prior to their IPO. Given this, when we examine Table 2 and Fig. 2 together, we begin to see that the financial condition of these firms appears to be deteriorating over the course of the study confirming our hypothesis $\left(\mathrm{H}_{7 \mathrm{~b}}\right)$.
Table 3 shows the descriptive statistics and correlations for the variables in our models. Due to outliers, we trim 14 of the 215 firms leaving us with 201 firms within our overall sample and 149 drug firms or 93.5 and $94.3 \%$ of our initial samples, respectively. Within Table 3, there are correlations between first-day mispricing and net proceeds only, and this relationship is negative. However, there are positive correlations between net proceeds and retained equity, research and development, ROA, venture capital involvement, and underwriter reputation. There is a negative correlation between net proceeds and stockholder equity. Included in Table 3 are the correlations for percentage change in stock price in the third year (i.e., a long-term variable $\left(\mathrm{H}_{7 \mathrm{a}}\right)$ ). This variable correlates only with net proceeds and age of the firm at the time of the IPO.

Table 4 presents the results from the multiple regression analyses. The second column shows that the age of the firm
Table 2 Mean financial indicators prior to IPO

\begin{tabular}{|c|c|c|c|c|c|c|c|}
\hline \multirow{11}{*}{$\begin{array}{l}\text { Table } 2 \text { Mean financial } \\
\text { indicators prior to IPO }\end{array}$} & Year & Net income & Total revenue & Total assets & $\mathrm{R} \& \mathrm{D}$ spending & ROA & Stockholder's equity \\
\hline & 1996 & $-4,944,830$ & $5,382,924$ & $22,849,338$ & $5,374,949$ & -0.438 & $8,025,000$ \\
\hline & 1997 & $-5,686,102$ & $4,761,448$ & $11,302,065$ & $4,893,740$ & -1.544 & $4,324,000$ \\
\hline & 1998 & $-7,771,388$ & $12,917,985$ & $25,828,656$ & $3,245,632$ & -1.202 & $6,138,000$ \\
\hline & 1999 & $-8,664,953$ & $8,497,419$ & $33,567,838$ & $10,113,488$ & -2.181 & $23,321,000$ \\
\hline & 2000 & $-12,221,155$ & $16,450,268$ & $38,368,458$ & $10,467,934$ & -0.936 & $-2,202,000$ \\
\hline & 2001 & $-15,673,496$ & $35,433,402$ & $49,054,671$ & $6,420,547$ & -0.950 & $11,828,000$ \\
\hline & 2002 & $8,773,362$ & $100,707,343$ & $158,915,794$ & $18,459,497$ & 0.462 & $3,104,000$ \\
\hline & 2003 & $-29,783,870$ & $1,097,071$ & $36,113,769$ & $13,026,547$ & -1.184 & $-59,895,000$ \\
\hline & 2004 & $-57,908,620$ & $17,357,379$ & $50,559,508$ & $17,716,472$ & -2.223 & $-50,161,000$ \\
\hline & 2005 & $-27,576,092$ & $12,171,484$ & $40,812,867$ & $16,143,245$ & -2.565 & $-50,958,000$ \\
\hline \multirow{3}{*}{$\begin{array}{l}N=215 \text { totals are based } \\
\text { on all data, not yearly means; } \\
\text { ROA = net income/total assets } \\
\text { ROA return on assets }\end{array}$} & 2006 & $-40,962,847$ & $34,392,899$ & $167,409,508$ & $17,205,654$ & -0.620 & $-25,681,000$ \\
\hline & 2007 & $-25,392,420$ & $61,77,579$ & $41,395,945$ & $18,714,222$ & -0.844 & $-37,054,000$ \\
\hline & Total & $-18,984,368$ & $16,269,115$ & $51,804,073$ & $11,935,175$ & -0.337 & $-14,589,000$ \\
\hline
\end{tabular}




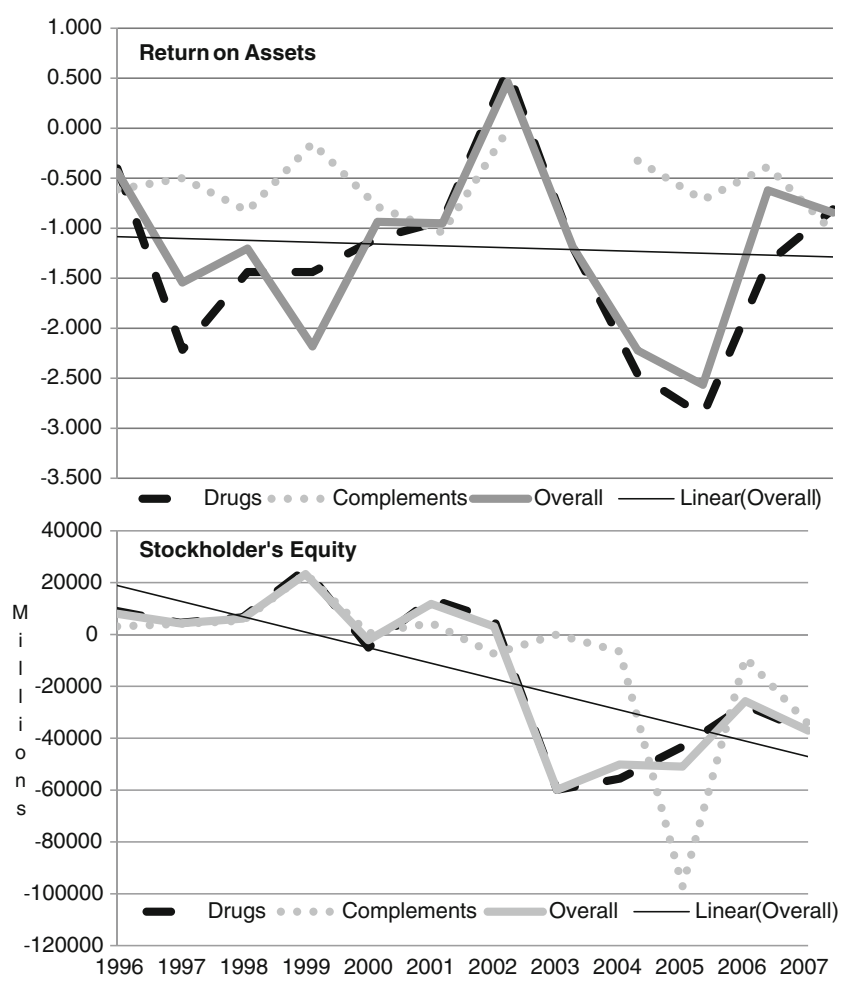

Fig. 2 Changes in financial condition over time. $N=215$

is the only variable of statistical significance that explains underpricing for all firms $(N=201)$. To assist with interpretation of the data, a natural log transformation was performed on several of the variables producing log normal distributions. To assess the potential multicollinearity issue, a variance inflation factor (VIF) analysis was performed. The results were VIF values below 2.0 for all variables which are well within the cutoff threshold of having VIF values of 10 or less. We also checked for homoscedasticity (i.e., the variance of errors is the same across all independent variables) by plotting the standardized residuals (the errors) by regression' predicted value. Residuals were fairly scattered around the horizontal line indicating little issue with heteroscedasticity.

The fourth column of Table 4 shows that there are no relationships between underpricing and our financial, intermediaries, or control variables for drug firms. Thus, many of our hypotheses related to underpricing (e.g., $\mathrm{H}_{1}$, $\mathrm{H}_{3 \mathrm{a}}, \mathrm{H}_{3 \mathrm{~b}}, \mathrm{H}_{5 \mathrm{a}}$, and $\mathrm{H}_{6 \mathrm{a}}$ ) are not supported. These results are the same whether we are examining all firms $(N=201)$ or drug firms only $(N=149)$. As noted in Table 4 , these variables explain very little of the variance of underpricing (e.g., 6.5 and $4.1 \%$, respectively).

We find very different results when we examine the net proceeds going to firms. For all firms $(N=201)$, two of our four financial indicators show a significant relationship with net proceeds. These are R\&D expenditures and ROA. Similar results are found when examining drug firms, with the

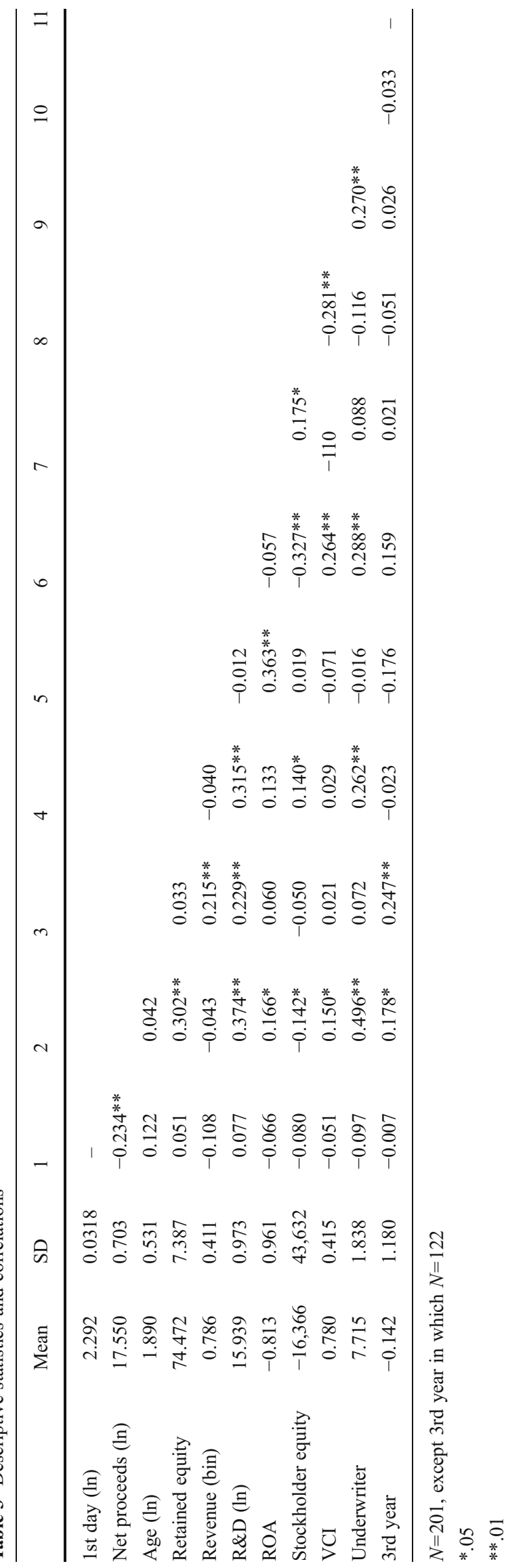


Table 4 Multivariate and logistic regression results

\begin{tabular}{|c|c|c|c|c|c|c|}
\hline Predictor variables & $\begin{array}{l}\text { Mispricing } \\
\text { All firms } \\
\text { (1996-2007) } \\
\text { Coefficient } \\
\text { estimates }\end{array}$ & $\begin{array}{l}\text { Net proceeds } \\
\text { All firms } \\
\text { (1996-2007) } \\
\text { Coefficient } \\
\text { estimates }\end{array}$ & $\begin{array}{l}\text { Mispricing } \\
\text { Drug firms } \\
\text { (1996-2007) } \\
\text { Coefficient } \\
\text { estimates }\end{array}$ & $\begin{array}{l}\text { Net proceeds } \\
\text { Drug firms } \\
\text { (1996-2007) } \\
\text { Coefficient } \\
\text { estimates }\end{array}$ & $\begin{array}{l}\text { Year } 3 \% \text { change } \\
\text { All firms } \\
\text { (1996-2004) } \\
\text { Coefficient } \\
\text { estimates }\end{array}$ & $\begin{array}{l}\text { 3rd-year survival } \\
\text { All firms } \\
\text { (1996-2004) } \\
\text { Wald coefficient }\end{array}$ \\
\hline Age & $0.146^{\mathrm{a}}$ & -0.037 & 0.167 & -0.023 & $0.253^{\mathrm{b}}$ & 2.037 \\
\hline Equity retained & 0.081 & 0.117 & 0.037 & $0.168^{\mathrm{a}}$ & -0.044 & 1.667 \\
\hline Revenue & -0.137 & -0.085 & -0.044 & $-0.162^{\mathrm{a}}$ & $0.290^{\mathrm{b}}$ & 1.050 \\
\hline R\&D expenditures (log) & 0.039 & $0.225^{\mathrm{b}}$ & -0.040 & $0.266^{\mathrm{b}}$ & 0.174 & 0.308 \\
\hline ROA & -0.011 & $0.174^{\mathrm{b}}$ & -0.020 & $0.171^{\mathrm{a}}$ & 0.187 & 0.007 \\
\hline Shareholder equity & -0.102 & -0.077 & -0.055 & -0.142 & -0.047 & 0.006 \\
\hline Venture capital & -0.070 & -0.024 & 0.007 & -0.097 & 0.010 & 2.284 \\
\hline Underwriter reputation & -0.134 & $0.384^{\mathrm{b}}$ & -0.109 & $0.319^{\mathrm{b}}$ & -0.117 & 2.326 \\
\hline$N$ & 201 & 201 & 149 & 149 & 122 & 121 \\
\hline$R^{2}$ & 0.065 & 0.348 & 0.041 & 0.336 & 0.153 & $0.070^{\mathrm{c}}$ \\
\hline
\end{tabular}

Coefficient estimates are standardized

${ }^{\text {a }}$ Significant at the 0.05 level

${ }^{\mathrm{b}}$ Significant at the 0.01 level

${ }^{\mathrm{c}}$ Statistic represents $R_{\mathrm{L}}{ }^{2}$

exception of revenue also having a statistically significant relationship with net proceeds. We believe that these results verify our hypothesis related to financial variables and net proceeds (e.g., $\mathrm{H}_{2}$ ), suggesting that firms in better financial condition receive more net proceeds. Our findings related to net proceeds and R\&D expenditures verifies our hypotheses (e.g., $\mathrm{H}_{4 \mathrm{a}}$ and $\mathrm{H}_{4 \mathrm{~b}}$ ), suggesting that firms that spend more on $\mathrm{R} \& \mathrm{D}$ in the year prior to the IPO are able to raise a greater amount of funds for further R\&D than firms that spend a lesser amount of funds on $R \& D$ in the year prior to the IPO. The old adage that one has to spend money to make money appears to apply in this setting.

We found mixed results related to our intermediaries. The findings do not support our hypotheses about venture capitalists being associated with higher underpricing (e.g., $\mathrm{H}_{5 \mathrm{a}}$ ) or net proceeds $\left(\mathrm{H}_{5 \mathrm{~b}}\right)$. Nor were underwriters with greater reputations associated with higher amounts of underpricing $\left(\mathrm{H}_{6 \mathrm{a}}\right)$. However, more prestigious underwriters were associated with IPOs that raised a greater amount of net proceeds $\left(\mathrm{H}_{6 \mathrm{~b}}\right)$.

Taken together, our findings suggest that public market investors do not place more emphasis on financial indicators or intermediaries when determining the price at which to buy the stock of an IPO than do premarket investors. However, certain financial variables and underwriter reputation do play a role when determining the total amount that a firm can raise in an IPO. Firms that generate revenue and spend more on $R \& D$ are able to raise a greater amount of funding for all firms, and drug firms in particular. Our model explains $34.8 \%$ of the variance of net proceeds for all firms and $33.6 \%$ of the variance of net proceeds for drug firms.

This paper also has an interest in long-term performance and survivability related to these variables. We test this interest by using firms from the years 1996 through the end of 2004. One hundred fifty-eight firms went public during this time. The last two columns of Table 4 begin to address this. The second to the last column shows the multiple regression results related to percentage change of stock price at year 3 on all firms that survived 3 years $(N=$ 122). The findings indicate that the age of the firm at the time of the IPO and its ability to generate revenue are the only variables related to 3 -year percentage changes in stock price. Thus, our hypothesis (e.g., $\mathrm{H}_{7 \mathrm{a}}$ ) is supported in a very limited manner.

The last column in Table 4 shows the results of our logistic regression related to our variables and overall survivability. This relates to our hypothesis (e.g., $\mathrm{H}_{8 \mathrm{a}}$ ) regarding pre-IPO financial condition and the ability to survive. We do not include firms from 2005, 2006, and 2007 in this analysis. Our sample includes 121 firms. In logistic regression when analyzing overall model fit, it is important to examine several statistical tests together. Given this, the results show that the model does not fit the data very well. This is indicated by a Model $\chi^{2}=8.230(p=0.411), a-2 \log$ likelihood $=109.465$, a Hosmer and Lemeshow test $=7.057(p=.530)$, and $R_{\mathrm{L}}{ }^{2}=$ 0.070 . All tests indicate a poor fit of the model to the data. Similarly, there are no statistically significant relationships among our independent variables and firm survival. The presentation of the Wald statistics in Table 4 signifies this, as do 
the logistic regression coefficients (not shown). We also ran stepwise logistic regression and found similar results (not shown).

To understand financial condition and survival further, we follow Peristiani and Hong's [16] example for all US IPOs. We perform a Cox regression model that allows us to explain the influence of explanatory variables in the survivor and hazard function. The dependent variable is the conditional probability that the biopharmaceutical IPO will delist given that it has not delisted previously. Following Peristiani and Hong [16], we use ROA to gauge its financial condition. We analyze all firms $(N=198)$ and the subset of firms from the years 1996 through $2004(N=139)$. We find similar results for both analyses. To be consistent with our previous logistic regression analysis, we present results related to firms that went public between 1996 through 2004 $(N=139)$. Fifty-eight or $41.7 \%$ of the firms did not survive (i.e., they delisted). Figure 3 graphs the survival of biopharmaceutical IPOs for different levels of pre-IPO financial condition. The top half of Fig. 3 shows the survival function at the mean of the covariates whereas the bottom half illustrates the data divided into quartiles. Our analysis of the mean indicates a poor fitting model $\left(\chi^{2}=1.321, p=\right.$ 0.250 , and a $-2 \log$ likelihood $=378.908$ ), with our analysis of the quartiles producing similar results (not shown). Our analysis provides a Wald coefficient $=1.315(p=0.252)$. Our quartile analysis of ROA also provides nonstatistically significant results (not shown). Interestingly, the quartile study shows that although not statistically significant, the firms in the 2nd and 4th ROA quartile survived on average longer than those firms in the 1 st and 3rd quartile. In addition, when we substitute any of the other three variables used as proxies for financial condition (e.g., revenue generation, research and development expenditures, or stockholder's equity), we get similar results (not shown). Thus, taken together with our logistic regression results, financial condition prior to the IPO does not appear to be a good indicator of survival. Thus, our hypothesis (e.g., $\mathrm{H}_{8 \mathrm{a}}$ ) regarding firm

Fig. 3 Survival analysis

Survival Function at Mean of Covariates

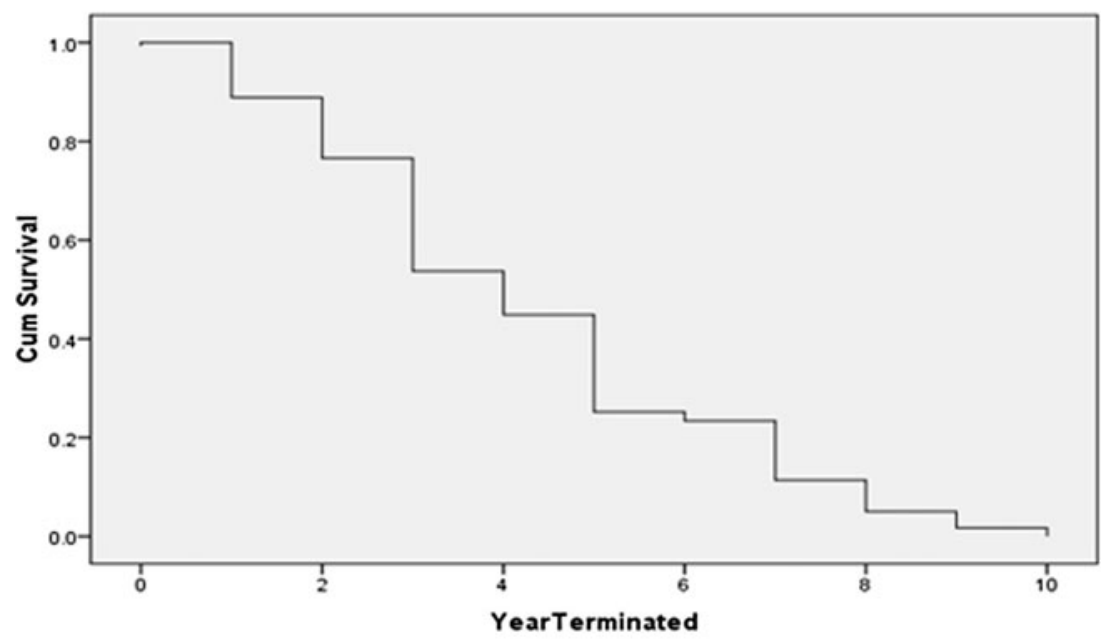

Survival Function at mean of covariates

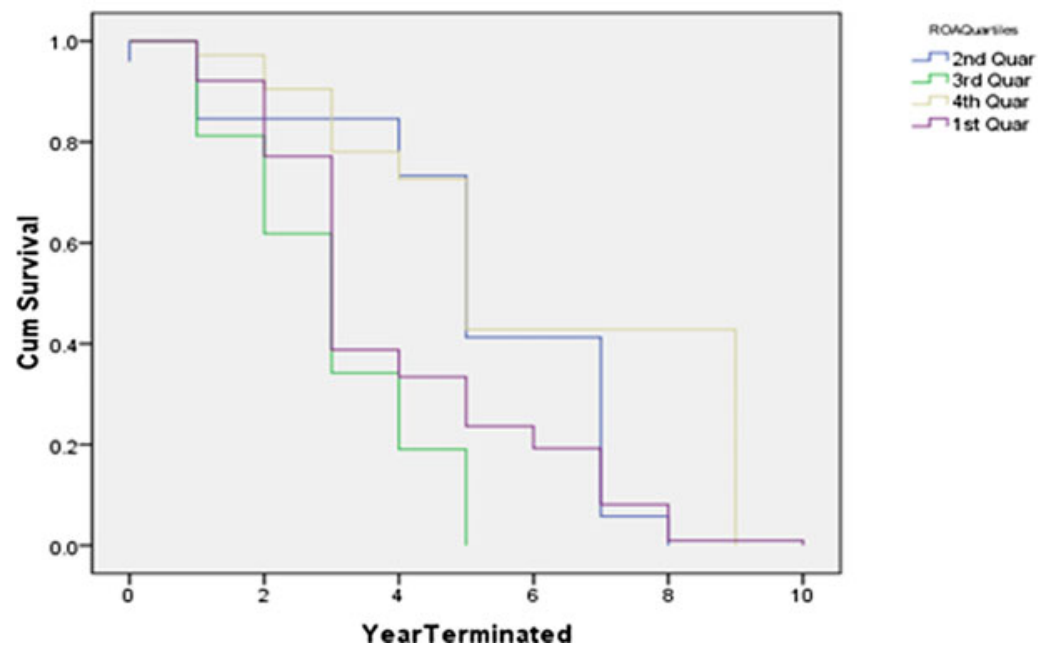


survival being associated with the financial condition of the firm at the time of the IPO is not supported.

We also perform a second Cox regression model to address our hypothesis (e.g., $\mathrm{H}_{8 \mathrm{~b}}$ ) regarding firm survival and amount of net proceeds raised $(N=139)$. The dependent variable is the conditional probability that the biopharmaceutical IPO will delist given that it has not delisted previously. Net proceeds collected at the time of the IPO are used. Again, we find no association between an independent variable (e.g., net proceeds) and firm survival. The results indicate that the model does not fit the data well. This is seen by a Model $\chi^{2}=0.532(p=0.466)$, a -2 Log likelihood $=379.632$, and an $R_{\mathrm{L}}{ }^{2}=0.001$. The Wald coefficient $=0.532(p=0.466)$ for net proceeds collected at the time of the IPO. We also re-ran our logistic regression including net proceeds collected at the time of the IPO in our model $(N=121)$. These results also show that the model does not fit the data very well. This is indicated by a Model $\chi^{2}=7.948(p=0.539)$ and a -2 Log likelihood=109.747. The Wald coefficient $=0.913(p=0.339)$ for net proceeds collected at the time of the IPO. We find similar results when we ran a stepwise logistic regression including all previous independent variables and a logistic regression with net proceeds as the only independent variable (results not shown). Thus, our hypothesis (e.g., $\mathrm{H}_{8 \mathrm{~b}}$ ) regarding firm survival being associated with the amount of net proceeds raised at the time of the IPO is not supported.

\section{Discussion}

The present paper examines the ways pre-IPO financial indicators and intermediaries affect aftermarket performance and survival of biopharmaceutical firms going public for the first time between the years 1996 through 2007. We choose biopharmaceutical firms to study due to their research intensity, and the fact that this market sector has been "fuelled by the financial community" ([63], p. 126). The findings may be of interests to scholars of biopharmaceutical management, biopharmaceutical firms, and investors.

Overall, we find mixed results. Biopharmaceutical firms raised over $\$ 12.5$ billion during this time, with first-day prices increasing over $16 \%$ on average. Pre-IPO financial indicators and intermediaries do not appear, however, to play a significant role in predicting this mispricing or the firm's survival. On the other hand, several indicators do play a significant role in explaining the amount a firm is able to raise during the IPO and its 3-year stock performance for surviving firms. Of note, R\&D spending prior to the IPO is significantly related to the amount of net proceeds collected. This is to say that aftermarket investors do not appear to place much value on financial indicators and intermediaries when deciding on the price to pay for an IPO's stock relative to what the underwriter pays. However, they do appear to place great value on financial indicators (e.g., revenue generation and ROA) when deciding how much net proceeds overall the firm can raise in an IPO.

In addition, underwriters play a significant role. Several prestigious underwriters included in this study (e.g., Lehman Brothers and Bear Stearns) no longer exist in the forms that they did during the study due to the economic crisis in the USA and internationally. Additionally, the IPO market has presently "dried up" for many firms [8]. Although we do not know how long the current instability in the markets may last, we nevertheless believe that similar factors previously affecting IPOs will be at play again and agree with Drennen [64] that biopharmaceutical firms that focus on innovation will continue to gain competitive advantage. Thus, we believe that market factors including underwriter prestige will in the future affect the amount that IPOs are able to raise.

An explanation for our findings may be a variation of Loughran and Ritter's [20] use of prospect theory in this setting. They suggest that pre-IPO investors are more tolerant of excessive underpricing if pre-IPO investors simultaneously learn about aftermarket valuation that is higher than what they expected (i.e., as the stock price rises in the aftermarket the pre-IPO's investors wealth goes up by way of the value of the stock retained). A different way of looking at this is from the aftermarket investor's perspective. Given the uncertainty of both the science and the IPO market (and perhaps especially after the internet bubble), aftermarket investors may view this market sector as primarily speculative in nature and de-emphasize the financial condition of the firm as it relates to stock price but not in their total amount that they are willing to invest. In other words, the aftermarket investors may discount significantly the financial condition of the firm in relation to the amount they are willing to pay for a given stock but not their total dollar amount expended. This would suggest that aftermarket investors are making smaller bets in firms in lesser financial condition compared with larger bets in firms in better financial condition.

As another explanation, we note that Leone et al. [49] found that IPOs that were more specific in their reporting of their use of proceeds from the IPO face lower underpricing. Our results on net proceeds may be similar in that firms that are spending more on $\mathrm{R} \& \mathrm{D}$ are able to raise greater amounts of funds - i.e., the firms are signaling their historical use of proceeds, and investors in this market sector wish their investment to be spent on R\&D. Thus, our findings suggest at least three relevant points for managers (especially managers of drug firms) to consider:

1. Within the IPO prospectus, other documents, and during the IPO process itself, the firm may wish to highlight the 
use of proceeds going to $\mathrm{R} \& \mathrm{D}$ - firms with greater $\mathrm{R} \& \mathrm{D}$ expenditures are able to raise more capital during the IPO;

2. Similarly, it should remain focused on R\&D - other areas such as marketing and manufacturing should be de-emphasized (outsourced?) to maintain focus on $\mathrm{R} \& \mathrm{D}$ and the ability to raise capital. It is important to notice that at this stage of development, having a positive ROA is important, but generating revenue itself is a negative influence on the ability to raise capital. This suggests that the markets want to see the firm focused on R\&D and should they generate revenue (few do), that they are efficient with this revenue generation (e.g., positive ROA);

3. Although our venture capital variable is nonsignificant, prior to engaging venture capitalists entrepreneurs may wish to ask the venture capitalists which underwriters they typically use. Venture capitalists have preferences for underwriters, and this may affect the overall amount raised in an IPO if the venture capitalists network with less reputable underwriters.

There are several limitations to our study. First, we focus on biopharmaceutical firms and do not know if our results are generalized to other high-technology firms or other firms in general. Second, we use delisting as our proxy for survival. This does not take into consideration that firms in our study may have been acquired as opposed to some other survival proxy such as bankruptcy. This is especially important given the widespread use of strategic alliances in this market sector. Thus, some poor-performing firms may have delisted due to financial condition whereas strategic alliance partners or other firms may have acquired some promising firms. This may be one explanation of the nonsignificant findings related to amount raised and survival. Third, it would be helpful to know if all shares of stock offered were sold during the IPO. This would further shed light on the issue related to financial condition and net proceeds collected (i.e., were firms in better financial condition able to sell all shares of stock compared to those in a state of lesser financial condition). Fourth, we would like to know what effect, if any, nonfinancial variables (e.g., stage of clinical trials, number of strategic alliances, and CEO background) have on our dependent variables. Finally, primary research is needed to understand how biopharmaceutical firms and investors view the relationships between preIPO financial condition and our dependent variables.

In conclusion, our findings suggest that financial condition does not affect the mispricing or underpricing of the firms. However, several financial indicators and having prestigious underwriters do play a significant role in terms of amount of capital raised. Additionally, firms that spent a greater amount on $R \& D$ were correlated with raising greater amounts of capital, suggesting that investors greatly value $\mathrm{R} \& \mathrm{D}$ expenditures in this market sector in terms of amount raised. Our results should assist biopharmaceutical firms, researchers, and investors understand the role these factors play in the IPO process.

\section{References}

1. Basu P, Joglekar G, Rai S, Suresh P, Vernon J. Analysis of manufacturing costs in pharmaceutical companies. J Pharm Innov. 2008;3:175-87.

2. Pharmaceutical Research and Manufacturers of America: Pharmaceutical industry profile 2007. http://www.phrma.org/files/Profile\%202007.pdf (2007). Accessed 15 March 2008.

3. DiMasi JA, Grabowski HG. The cost of biopharmaceutical R\&D: is biotech different? Manag Decis Econ. 2007;28:469-79.

4. Carleysmith SW, Dufton AM, Altria KD. Implementing lean sigma in pharmaceutical research and development: a review by practitioners. R\&D Manag. 2009;39(1):95-106.

5. Danzon PM, Nicholson S, Pereira NS. Productivity in pharmaceuticalbiotechnology R\&D: the role of experience in alliances. J Health Econ. 2005;24(2):317-39.

6. Grabowski HG, Vernon JM. Returns to R\&D on new drug introductions in the 1980s. J Health Econ. 1994;13(4):383-407.

7. Willigers BJA, Hansen TL. Project valuation in the pharmaceutical industry: a comparison of least-squares Monte Carlo real option valuation and conventional approaches. R\&D Manag. 2008;38 (5):520-37.

8. Mitchell P. Biotech sector ponders bloodbath. Nat Biotechnol. 2009;27(1):3-5.

9. Williams DR, Duncan WJ, Ginter PM. Testing a model of signals in the IPO offer process. Small Bus Econ. 2010;34(4):445-63.

10. Lerner J, Merges RP. The control of technology alliances: an empirical analysis of the biotechnology industry. J Ind Econ. 1998;46(2):125-56.

11. Nicholson S, Danzon PM, McCullough J. Biotech-pharmaceutical alliances as a signal of asset and firm quality. J Bus. 2005;78 (4):1433-64.

12. Marshall BB, Crutchley CE, Lending D. Early internet IPOs versus subsequent entrants. J Econ Finance. 2004;28(1):104-16.

13. Guirguis HS, Onochie J, Rosen H. The post-offering performance of IPOs in the health care industry. J Econ Finance. 2001;25 (2):194-205.

14. Williams DR, Duncan WJ, Ginter PM, Shewchuk RM. Do governance, equity characteristics, and venture capital involvement affect long-term wealth creation in U.S. healthcare and biotechnology IPOs? J Health Care Finance. 2006;33(1):54-71.

15. Ritter JR, Welch I. A review of IPO activity, pricing, and allocations. J Finance. 2002;55(4):1795-828.

16. Peristiani S, Hong G. Pre-IPO financial performance and aftermarket survival. Current Issues in Econ Fin. http://www.newyorkfe d.org/research/current_issues (2004). Accessed 4 May 2010.

17. Tozzi J. Advice for startups seeking venture capital. Business week. http://www.businessweek.com/smallbiz/content/dec2008/ sb2008121 215435.htm (2008). Accessed 11 Dec 2008.

18. Winstein KJ. Cash dries up for biotech drug firms. Wall St J. http:// online.wsj.com/article/SB123723284124846013.html (2009). Accessed 17 March 2009.

19. Daily CM, Certo ST, Dalton DR, Roengpitya R. IPO underpricing: a meta-analysis and research synthesis. Entrepren Theor Pract. 2003;27(3):271-95. 
20. Loughran T, Ritter JR. Why don't issuers get upset about leaving money on the table in IPOs? Rev Financ Stud Spec. 2002;15 (2):413-43.

21. Loughran T, Ritter JR. Why has IPO underpricing changed over time? Financ Manag. 2004;33(3):5-38.

22. National Venture Capital Association: 2007 Venture capital investing hits six year high at \$29.4 billion. http://www.nvca.org (2008). Accessed 21 Feb 2008.

23. Ernst, Young: Enduring strengths - and the strength to endure. Beyond Borders: Global Biotechnology Report 2008 22-24. http://www.ey.com/Global/assets.nsf/International/Industry_Bio technology_Beyond_Borders_2008/\$file/Biotechnology_Be yond Borders 2008.pdf (2008). Accessed 30 Oct 2009.

24. Winslow R. Genentech's Levinson sets the record straight on DNA. Wall St J. Online (2009). Accessed 14 Jan 2009.

25. Guo R, Lev B, Zhou N. The valuation of biotech IPOs. J Account Audit Finance. 2005;20(4):423-59.

26. Loughran T, Ritter JR. The new issue puzzle. J Finance. 1995;50 (1):23-51.

27. Ritter JR. The hot issue market of 1980. J Bus. 1984;57(2):21540.

28. Ibbotson RG, Jaffe JF. Hot issue markets. J Finance. 1975;30 (4):1027-42.

29. Williams DR, Young CC. Trends in biopharmaceutical IPOs: 1996-2005. J Health Care Finance. 2006;33(2):39-54.

30. Aggarwal R, Rivoli P. Evaluating the cost of raising capital through an initial public offering. J Bus Ventur. 1991;6:351-61.

31. Chen HC, Ritter JR. The seven percent solution. J Finance. 2000;55(3):1105-31.

32. Ritter JR. The long-run performance of initial public offerings. J Finance. 1991;45(1):3-27.

33. Krigman L, Shaw H, Womack KL. The persistence of IPO mispricing and the predictive power of flipping. J Finance. 1999;44 (3):1015-44.

34. Yong $\mathrm{O}$, Isa Z $\mathrm{Z}$. Initial performance of new issues of shares in Malaysia. Appl Econ. 2003;35:919-30.

35. Nimalendran M, Ritter JR, Zhang D. Do today's trades affect tomorrow's IPO allocations? J Financ Econ. 2007;84:87-109.

36. Rock K. Why new issues are underpriced. J Financ Econ. 1982;15 $(1 / 2): 187-212$.

37. Tinic SM. Anatomy of initial public offerings of common stock. J Finance. 1988;43(4):789-822.

38. Shiller RJ. Speculative prices and popular models. J Econ Perspect. 1990;4:55-65.

39. Baron DP. A model of the demand for investment banking advising and distribution services for new issues. J Finance. 1982;37 (4):955-76.

40. Spence M. Job market signaling. Q J Econ. 1973;87(3):355-74.

41. Higgin MC, Gulati R. Stacking the deck: the effects of top management backgrounds on investor decisions. Strat Manag J. 2006;27(1):1-25.

42. Kahneman D, Tversky A. Prospect theory: an analysis of decision under risk. Econometrica. 1979;47(2):263-92.

43. Tan PM, Lim CY. The value relevance of accounting variables and analysts' forecasts: the case of biotechnology firms. Rev Acc Finance. 2007;6(3):233-53.
44. Xu B. R\&D strategy and stock price volatility in the biotechnology industry. Rev Acc Finance. 2006;5(1):59-71.

45. Arthurs JD, Hoskisson RE, Busenitz LW, Johnson RA. Managerial agents watching other agents: multiple agency conflicts regarding underpricing in IPO firms. Acad Manag J. 2008;51(2):277-94.

46. Howells J, Gagliardi D, Malik K. The growth and management of R\&D outsourcing: evidence from UK pharmaceuticals. R\&D Manag. 2008;38(2):205-19.

47. Suresh P, Basu PK. Improving pharmaceutical product development and manufacturing: impact on cost of drug development and cost of goods sold of pharmaceuticals. J Pharm Innov. 2008;3:17587.

48. Robbins-Roth C. From alchemy to IPO. New York: Perseus; 2000.

49. Leone AJ, Rock S, Willenborg M. Disclosure of intended use of proceeds and underpricing of initial public offerings. J Account Res. 2007;45(1):111-53.

50. Costa-Font J, Mossialos E. The public as a limit to technology transfer: the influence of knowledge and beliefs in attitudes towards biotechnology in the UK. J Technol Transf. 2006;31:62945.

51. Kelm KM, Narayanan VK, Pinches GE. The response of capital markets to the R\&D process. Technol Forecast Soc Change. 1995;49:75-88.

52. McCutchen WW, Swamidass PM. Effect of R\&D expenditures and funding strategies on the market value of biotech firms. J Eng Technol Manag. 1996;12:287-99.

53. Fernando CS, Krishnamurthy S, Spindt PA. Are share price levels informative? Evidence from the ownership, pricing, turnover and performance of IPO firms. J Financ Mark. 2004;7:377-403.

54. Kortum S, Lerner J. Assessing the contribution of venture capital to innovation. RAND J Econ. 2000;31(4):674-2.

55. Messica A, Agmon T. Venture capital, the public sector and the high-technology industry. Int J Enterp Inf Manag. 2008;5(1):10522.

56. Fama EF. Efficient capital markets: a review of theory and empirical work. J Finance. 1970;25:383-417.

57. Jain BA, Kini O. The post-issue operating performance of IPO firms. J Finance. 1994;44(5):1699-726.

58. Golec J, Vernon J. New estimates of pharmaceutical research and development spending by US-based firms from 1984 to 2003. Manag Decis Econ. 2007;28:4881-3.

59. Williams D, Pouder R. R\&D spending and sources of funding of private U.S. biopharmaceutical firms seeking to go public. J Commun Biotechnol. 2010;16(4):284-92.

60. Pratt SE, Bokser D. Pratt's guide to venture capital sources. Wesley Hills: Capital; 1996.

61. Carter RB, Dark FH, Singh AK. Underwriter reputation, initial returns and the long-run performance of IPO stocks. J Finance. 1998;53(1):285-311.

62. Carter R, Manaster S. Initial public offerings and underwriting reputation. J Finance. 1990;45(4):1045-67.

63. Riccaboni M, Moliterni R. Managing technological transitions through R\&D alliances. R\&D Manag. 2009;39(2):124-35.

64. Drennen JK. Scientific evolution and technical innovation. J Pharm Innov. 2009;4:155. 